\title{
IMPLEMENTASI KETENTUAN PASAL 50 UNCLOS DI WILAYAH NEGARA KEPULAUAN
}

(Implementation of Article 50 UNCLOS on Archipelagic States)

\author{
Sigit Sutadi Nugroho \\ Kepala Sub Bagian Hukum Laut Internasional \\ pada Pusat Hidrografi dan Oseanografi TNI Angkatan Laut \\ Jl. Pantai Kuta V No.1 Ancol Timur, Pademangan, Jakarta-Utara, Indonesia, 14430 \\ e-mail: sigitsutadinugroho@gmail.com
}

Naskah diterima: 23 April 2019; revisi: 21 Juli 2019; disetujui: 2 Agustus 2019

\begin{abstract}
Abstrak
United Nations Convention on the Law of the Sea telah mendapat pengakuan sebagai a Constitution for the Oceans, yang mengatur mengenai negara kepulauan. Ketentuan mengenai negara kepulauan diatur dalam bab sendiri pada Bab IV yakni Pasal 46 sampai dengan Pasal 54. Tulisan ini mencoba untuk mengkaji bagaimana praktik negara-negara kepulauan dalam menerapkan ketentuan Pasal 50 UNCLOS. Penelitian ini adalah penelitian normatif, alat pengumpulan data yang digunakan dalam penelitian ini adalah melalui studi dokumen, sehingga data yang digunakan adalah data sekunder dan teknik analisis yang digunakan adalah analisis isi (content analysis). Dari tulisan ini dapat disimpulkan bahwa terdapat negara kepulauan yang telah mengakomodir Pasal 50 UNCLOS dalam perundang-undangan nasionalnya dan telah mengimplentasikannya, terdapat negara yang telah mengakomodir dalam perundang-undangan nasionalnya, namun belum mengimplementasikan ketentuan tersebut. Selain itu, terdapat pula negara kepulauan yang berpandangan lain terhadap perairan pedalamannya. Indonesia termasuk negara kepulauan yang telah mengakomodir ketentuan Pasal 50 UNCLOS pada ketentuan nasionalnya, tetapi belum mengimplementasikannya. Perkembangan terkini Pemerintah Republik Indonesia dalam hal ini Kementerian Kordinator Bidang Kemaritiman telah menginisiasi penetapan batas perairan pedalaman Indonesia dengan melibatkan Badan Informasi Gesopasial, Pusat Hidrografi dan Oseanografi TNI Angkatan Laut dan ahli teknis di bidang Geodesi.

Kata Kunci: negara kepulauan, perairan pedalaman, UNCLOS.
\end{abstract}

\begin{abstract}
United Nations Convention on the Law of the Sea has been recognized as the Constitution for the Oceans, which regulates the archipelagic states. Provisions regarding archipelagic states have been regulated in in Chapter IV Article 46 to Article 54. This paper seeks to examine how this provision Article 50 UNCLOS 1982 is applied by the archipelagic states. This research is normative study, the data aids used in this study is using document studies, so that the data used is secondary data and the analysis technique used is content analysis. From this provision, it can be concluded that there are archipelagic states that have accommodated Article 50 UNCLOS in their national provisions and have implemented it, but there are also several also countries that have accommodatedit in its national provisions and have not implemented it yet. There is also an archipelagic states that has a different view of its internal waters. Indonesia is an archipelagic states that has accommodated Article 50 UNCLOS in its national provisions but has not yet implemented it. The latest development of the Government of the Republic of Indonesia in this case the Coordinating Ministry for Maritime Affairs has initiated the determination of Indonesian internal waters by involving the Geospatial Information Agency, the Hydrographic and Oceanographic Center of Indonesian Navy and technical experts in the field of Geodesy.
\end{abstract}

Keywords: archipelagic states, internal waters, UNCLOS. 


\section{A. Pendahuluan}

Konsepsi negara kepulauan telah dituangkan kedalam beberapa asas yang dinamakan asas-asas negara kepulauan (archipelagic states principles) dan tercantum dalam Bab IV United Nations Convention on the Law of the Sea 1982 (UNCLOS) yang terdiri dari sembilan pasal yakni Pasal 46 - 54, yang berisi antara lain ketentuan-ketentuan tentang negara kepulauan, garis-garis pangkal kepulauan, status hukum dari perairan kepulauan, penetapan perairan pedalaman dalam perairan kepulauan, hak lintas damai melalui perairan kepulauan, hak lintas alurlaur laut kepulauan, hak dan kewajiban kapal dan pesawat udara asing dalam pelaksanaan hak lintas alur-alur laut kepulauan. ${ }^{1}$

Prinsip negara kepulauan diterima sebagai suatu paket. Di satu sisi, negara-negara lain mengakui kedaulatan penuh negara kepulauan atas perairan kepulauan, dasar laut dan tanah di bawahnya, serta ruang udara di atas perairan kepulauan. Di sisi lain, negara kepulauan menghormati hak-hak yang dimiliki negara lain di perairan kepulauan². Diantaranya yaitu, kapal semua negara menikmati hak lintas damai melalui perairan kepulauan ${ }^{3}$ dan semua kapal, pesawat udara menikmati hak lintas alur laut kepulauan dalam alur laut dan rute penerbangan. ${ }^{4}$
Tidak ada lintas damai bagi kapal asing di perairan pedalaman, kecuali dalam hal penetapan garis pangkal lurus sesuai dengan cara yang ditetapkan dalam Pasal 7 UNCLOS berakibat tertutupnya sebagai perairan pedalaman daerah-daerah yang sebelumnya tidak dianggap demikian, maka di dalam perairan demikian akan berlaku suatu hak lintas damai sebagaimana ditentukan dalam UNCLOS $^{5}$. Di perairan pedalaman, kedaulatan negara pantai pada dasarnya adalah mutlak dan kapal-kapal asing pun tidak mempunyai hak lewat di wilayah ini tanpa izin dari Negara pantai ${ }^{6}$. Khusus Negara kepulauan hak lintas damai diatur dalam Pasal 52 UNCLOS yang menentukan bahwa dengan tunduk pada ketentuan Pasal 53 dan tanpa mengurangi arti ketentuan Pasal 50 kapal semua Negara menikmati hak lintas damai melalui perairan kepulauan sesuai dengan ketentuan dalam Bab II, bagian $3^{7}$. Secara substansi tidak ada perbedaan dengan konsep lintas damai Negara pantai.

Dalam ketentuan internasional UNCLOS terdapat ketentuan yang mengatur mengenai perairan pedalaman ${ }^{8}$. Selain itu pengaturan mengenai penentuan batas perairan pedalaman juga telah terdapat dalam peraturan nasional beberapa negara kepulauan di dunia seperti Antigua dan Barbuda, Cape Verde, Komoro, Fiji, dan

United Nations Convention on the Law of the Sea, Ps. 46-54.

Arif Havast Oegroseno, "Archipelagic States: From Concept To Law", The Imli Manual On International Maritime Law: Valome I The Law of the sea (2014):132.

United Nations Convention on the Law of the Sea, Ps.52.

Ibid, Ps.53.

Ibid, Ps. 8 .

6 Arie Afriansyah, "Kewenangan Negara Pantai Dalam Mengelola Wilayah Laut", (Makalah disampaikan pada Forum Diskusi Aktual (FDA), "Kewenangan Daerah Provinsi Di Laut", Badan Penelitian dan Pengembangan, Kementerian Dalam Negeri, Jakarta, 24 Agustus 2015).

7 Ibid, Ps.52.

$8 \quad$ Undang-Undang Nomor 6 Tahun 1996, Ps. 3 dan Ps, 7. 
Filipina. Dalam pengaturan nasional Indonesia telah terdapat Undang-Undang Nomor 6 Tahun 1996 tentang Perairan Indonesia yang merupakan tindak lanjut pengesahan UNCLOS. Pada ketentuan tersebut diatur bahwa perairan pedalaman Indonesia adalah semua perairan yang terletak pada sisi darat dari garis air rendah dari pantai-pantai Indonesia, termasuk kedalamnya semua bagian dari perairan yang terletak pada sisi darat dari suatu garis penutup. Serta di dalam perairan kepulauan untuk penetapan batas perairan pedalaman, Pemerintah Indonesia dapat menarik garis-garis penutup pada mulut sungai, kuala, teluk, anak laut dan pelabuhan ${ }^{9}$.

Undang-Undang Nomor 6 Tahun 1996 juga memuat ketentuan hak dan kewajiban kapal dan pesawat udara asing dalam melaksanakan hak lintas alur laut kepulauan, yang diatur lebih lanjut dalam Peraturan Pemerintah Nomor 37 Tahun 2002. Pada peraturan pemerintah tersebut diatur bahwa kapal dan pesawat udara asing dapat melaksanakan hak lintas alur laut kepulauan, untuk pelayaran atau penerbangan dari satu bagian laut bebas atau zona ekonomi ekslusif ke bagian lain laut bebas atau zona ekonomi ekslusif melintasi laut teritorial dan perairan kepulauan Indonesia ${ }^{10}$. Namun, dalam melaksanakan lintas alur laut kepulauan, selama melintas tidak boleh menyimpang lebih dari 25 (dua puluh lima) mil laut ke kedua sisi dari garis sumbu alur laut kepulauan, dengan ketentuan bahwa kapal dan pesawat udara tersebut tidak boleh berlayar atau terbang dekat ke pantai kurang dari 10\% (sepuluh per seratus) jarak antara titik-titik yang terdekat pada pulau-pulau yang berbatasan dengan alur laut kepulauan tersebut ${ }^{11}$.

Dengan kondisi geografis wilayah Indonesia yakni tersebarnya pulau-pulau di wilayah perairan Indonesia, terdapat pulau yang masuk kedalam deviasi alur laut kepulauan 25 (dua puluh lima) mil laut pada sisi dari garis sumbu alur laut kepulauan, dan diantara pulau tersebut terdapat teluk, mulut sungai serta instalasi pelabuhan, yang berdasarkan UNCLOS dan ketentuan nasional Indonesia dapat ditentukan sebagai perairan pedalaman, sehingga rezim yang berlaku adalah rezim perairan pedalaman.

Negara-negara pantai menikmati yurisdiksi teritorial penuh dan lengkap atas perairan pedalaman. Karenanya, kapal asing yang berada di pelabuhan atau bagian dari perairan pedalaman lainnya, tunduk pada yurisdiksi negara pantai. Namun, yurisdiksi tersebut dibatasi oleh tuntutan aturan umum dari hukum internasional seperti prinsip nondiskriminasi dan larangan penyalahgunaan hak $^{12}$. Hukum yang berlaku di perairan pedalaman, memiliki karakter rejim hukum yang sama dengan daratan dan setiap kapal yang memasuki perairan pedalaman maka berlakulah hukum nasional negara pantai tersebut terhadapnya. Sehingga setiap kapal yang memasuki pelabuhan dan perairan

\footnotetext{
Undang-Undang Nomor 6 Tahun 1996, Ps. 3 dan Ps, 7.

Peraturan Pemerintah Nomor 37 Tahun 2002, Ps. 2.

Peraturan Pemerintah Nomor 37 Tahun 2002, Ps. 4.

12 Haijiang Yang, Jurisdiction of the Coastal State over Foreign Merchant Ships in Internal Waters and the Territorial Sea (Heidelberg: Springer Berlin, 2006), hlm.83.
} 
pedalaman, maka itu berarti kapal tersebut telah tunduk pada kedaulatan negara pantai ${ }^{13}$.

Untuk memberikan perlindungan negara pantai atas lintas yang dilakukan oleh kapal asing di dalam perairan pedalamannya, UNCLOS memberikan hak negara pantai untuk mengambil langkah-langkah yang diperlukan untuk mencegah pelanggaran bagi masuknya kapal di perairan pedalaman ${ }^{14}$. Hukum internasional memberikan kewenangan kepada negara untuk membuat peraturan hukum, mengatur penggunaan perairan pedalamannya dan memutuskan siapa saja yang boleh memasuki, yang boleh keluar serta hal-hal yang boleh dilakukan saat memasuki perairan pedalaman ${ }^{15}$.

Berdasarkan latar belakang yang telah diuraikan di atas, maka penulis mengidentifikasikan permasalahan terkait dengan penerapan Pasal 50 UNCLOS oleh Negara-negara Kepulauan dalam melakukan delimitasi perairan pedalaman di dalam wilayah kepulauannya. Dalam menjawab permasalahan tersebut dalam tulisan ini akan membahas mengenai negara kepulauan, perairan pedalaman dan praktik negara kepulauan dalam menerapkan Pasal 50 UNCLOS.

\section{B. Metode Penelitian}

Jenis penelitian yang digunakan dalam penelitian ini adalah penelitian normatif, dimana metode ini melihat hukum sebagai apa yang tertulis dalam peraturan perundang- undangan atau hukum dikonsepkan sebagai kaidah atau norma yang merupakan patokan berperilaku manusia yang dianggap pantas ${ }^{16}$. Dalam penulisan artikel ini, penulis menggunakan penelitan yuridis normatif. Sehubungan dengan topik penelitian ini, maka peneliti akan mendasarkan pada ketentuan hukum internasional mengenai penarikan garis-garis penutup untuk keperluan batas perairan pedalaman. Peraturan tersebut berupa UNCLOS dan peraturan-peraturan nasional negara kepulauan dalam menetapkan delimitasi batas perairan pedalaman. Alat pengumpulan data yang digunakan dalam penelitian ini adalah melalui studi dokumen sehingga data yang digunakan adalah data sekunder dan teknik analisis yang digunakan adalah analisis isi (content analysis).

Beberapa bahan hukum yang digunakan dalam penelitian ini, antara lain:

1. Bahan hukum primer berupa hukum positif berupa United Nations Convention on the Law of the Sea 1982, Antigua and Barbuda Maritime Areas Act 1982, Cape Verde Decree-Law No. 126/77 of 31 December 1977, Comoros Law No. 82005 relating to the delimitation of the maritime zones of the Islamic Federal Republic of the Comoros, 28 July 1982, Fiji Marine Spaces (Archipelagic Baselines and Exclusive Economic Zone) Order, 1981, Undang-Undang-RI Nomor 6 Tahun 1996 tentang Perairan Indonesia, dan Philippines Republic Act No. 3046 of 17

R.R Churchill and A.V. Lowe, The Law of the Sea (Manchester: Manchester University Press, 1988) hlm.50-54. Ibid, Ps.25.

15 Lung Chu Chen. An Introduction to Contemporary International Law Policy Oriented Perspective $2^{\text {nd }}$ Edition (New Haven : Yale University Press, 2000), hlm.133.

16 Amirrudin dan H. Zainal Asikin, Pengantar Metode Penelitian Hukum, (Jakarta: PT. Raja Grafindo Persada, 2004), hlm 118. 
June 1961. An Act to Define the Baselines of the Territorial Sea of the Philippines;

2. Bahan hukum sekunder yang meliputi buku, jurnal ilmiah, artikel dan berita di surat kabar, majalah dan internet.

3. Bahan hukum tersier yang meliputi kamus hukum dan ensiklopedi. Sebagai bahan pendukung dan data-data yang diambil dari data sekunder, penulis melakukan wawancara dengan nara sumber yang relevan yaitu Kementerian Koordinator Bidang Kearitiman, Badan Informasi Geospasial, Pusat Hidrografi dan Oseanografi TNI Angkatan Laut.

\section{Pembahasan}

\section{Negara Kepulauan}

Pengaturan dalam Bab IV UNCLOS 1982 dimulai dengan ketentuan mengenai negara kepulauan (archipelagic states), dengan perkataan lain UNCLOS 1982 memberikan dasar pengaturan dalam bentuk definisi yuridis tentang apa yang dinamakan suatu "Negara Kepulauan" yang sudah barang tentu berbeda dengan definisi negara yang secara geografis wilayahnya berbentuk kepulauan. Selain itu Pasal 46 juga membedakan pengertian yuridis antara negara kepulauan dengan kepulauan (archipelago) itu sendiri ${ }^{17}$. Negara Kepulauan berarti suatu negara yang seluruhnya terdiri dari satu atau lebih kepulauan dan dapat mencakup pulau-pulau lain. Sedangkan kepulauan berarti suatu gugusan pulau, termasuk bagian pulau, perairan di antaranya dan lain-lain wujud alamiah yang hubungannya satu sama lainnya demikian eratnya sehingga pulau-pulau, perairan dan wujud alamiah lainnya itu merupakan suatu kesatuan geografi, ekonomi dan politik yang hakiki, atau yang secara historis dianggap sebagai demikian ${ }^{18}$.

UNCLOS menyatakan setiap Negara kepulauan dapat menarik garis pangkal lurus kepulauan yang menghubungkan titik-titik terluar pulau-pulau dan karang kering terluar dari kepulauan. Panjang garis yang demikian maksimal adalah 100 mil laut dan 3 persen dari jumlah seluruh garis pangkal yang ada dapat melebihi kepanjangan tersebut, hingga maksimal 125 mil laut. Dari garis pangkal lurus kepulauan tersebut diukur lebar laut territorial, zona tambahan, zona ekonomi ekslusif serta landas kontinen suatu negara kepulauan. Perairan yang terletak di sisi dalam garis pangkal lurus kepulauan tanpa memperhatikan kedalamannya atau jaraknya dari pantai, berada di bawah kedaulatan negara kepulauan yang bersangkutan, dan disebut sebagai perairan kepulauan. Kedaulatan tersebut meliputi pula ruang udara di atas perairan kepulauan, tanah dibawahnya serta kekayaan yang terkandung didalamnya. Selanjutnya di dalam perairan kepulauan, negara kepulauan dapat menarik garis-garis penutup untuk keperluan penetapan batas perairan pedalamannya, bagi mulut sungai, teluk dan pelabuhan.

\section{Perairan Pedalaman}

Pengaturan perairan pedalaman pada UNCLOS diatur dalam Pasal 8 dan Pasal 50. Pasal 8 mengatur perairan pedalaman bagi

\footnotetext{
17 Etty R. Agoes, "Praktik Negara-Negara Atas Konsepsi Negara Kepulauan," Indonesian Jurnal of International Law (2004), HIm. 445.

18 United Nations Convention on the Law of the Sea, Ps.46.
} 
negara pantai bahwa kecuali sebagaimana diatur dalam Bab IV, perairan pada sisi darat garis pangkal laut teritorial merupakan bagian perairan pedalaman negara tersebut. Sedangkan Pasal 50 merupakan ketentuan yang berlaku bagi negara kepulauan untuk menarik garis-garis penutup untuk keperluan penetapan batas perairan pedalaman di perairan kepulauannya.

\section{a. Penarikan Batas Perairan Pedalaman.}

1) Mulut Sungai

Jika di tepi sebuah pulau/daratan, terdapat sungai yang mengalir langsung kelautan maka mulut sungai yang mengalir langsung ke lautan maka mulut sungai tersebut dapat ditutup dengan sebuah garis lurus yang merupakan satu kesatuan sistem garis pangkal. Garis lurus ini harus ditentukan dengan menghubungkan dua titik pada garis air rendah melintasi mulut sungai seperti dinyatakan dalam Pasal 9 UNCLOS 1982.

Pada kenyataannya, tidak mudah menentukan secara tepat posisi titik-titik yang membentuk mulut sungai, terutama jika garis pantainya mulus. Konsekuensinya, sulit menentukan titik awal dan akhir garis lurus penutup mulut sungai sehingga panjang garis bisa beragam tergantung posisi titik awal dan akhirnya. Meski demikian, negara pantai biasanya akan menentukan titik-titik itu dengan seksama (hati-hati), walaupun Pasal 9 UNCLOS tidak mengindikasikan batasan spesifik tentang panjangan maksimum garis penutup mulut sungai tersebut.

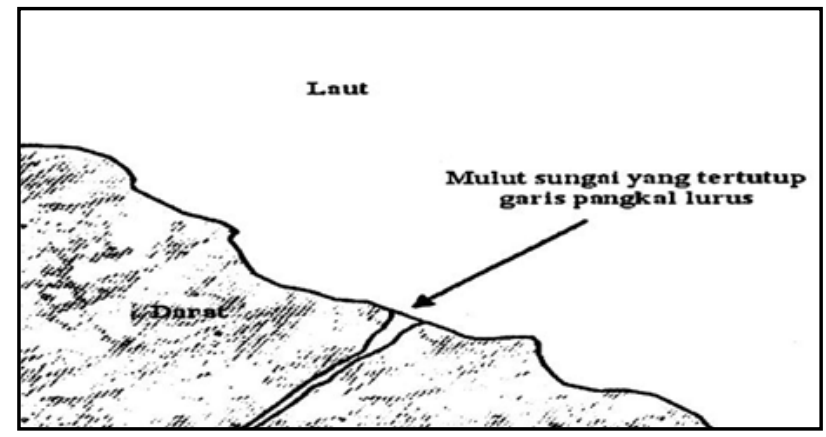

Gambar 1. Penutupan Mulut Sungai Untuk Perairan Pedalaman

Sumber : I Made Andi Arsana, Batas Maritim Antarnegara, Sebuah Tinjauan Teknis dan Yuridis (Yogyakarta: Gadjah Mada University Press, 2007), hlm.30.

Hal lain yang perlu diperhatikan terkait dengan garis pangkal penutup mulut sungai adalah untuk sungai yang memasuki lautan tidak secara langsung melainkan melalui estuari (estuary). Dalam hal ini penentuan garis pangkal harus mengikuti aturan sebagaimana menentukan garis pangkal untuk penutup teluk. Persoalan selanjutnya adalah bahwa tidak mudah untuk menentukan secara pasti apakah sebuah sungai mengalir ke laut melalui estuari atau tidak. Churchill dan Lowe menegaskan bahwa tidak kepastian ini seringkali disalahgunakan oleh negara pantai dalam menafsirkan kemungkinan garis pangkalnya untuk menguntungkan negara pantai tersebut ${ }^{19}$.

\section{2) Teluk}

Pasal 10 UNCLOS menentukan pendefinisian garis penutup teluk. Pasal ini mengatur metode penentuan jenis teluk dan menegaskan bahwa teluk ini harus ditutup dengan garis pangkal lurus. Faktor relevan yang mempengaruhi adalah bentuk teluk,

19 I Made Andi Arsana, Batas Maritim Antarnegara, Sebuah Tinjauan Teknis dan Yuridis (Yogyakarta: Gadjah Mada University Press, 2007), hlm. 30. 
luas teluk dan nilai sejarah teluk tersebut bagi negara pantai yang bersangkutan. Mengenai bentuknya, Pasal 10 UNCLOS menyatakan bahwa teluk adalah bagian laut yang secara jelas teramati menjorok kedaratan yang jarak masuknya dan lebar mulut teluknya memenuhi perbandingan tertentu yang memuat wilayah perairan dan bukan sekedar lekukan pantai. Luas teluk ini juga harus lebih besar dari luas setengah lingkaran yang diameternya adalah garis penutup teluk. Sebagai tambahan, panjang garis pangkal lurus yang menutup mulut teluk tidak boleh melebihi 24 mil laut, walaupun ketentuan ini tidak berlaku pada teluk yang disebut teluk sejarah (historic bays) ${ }^{20}$.

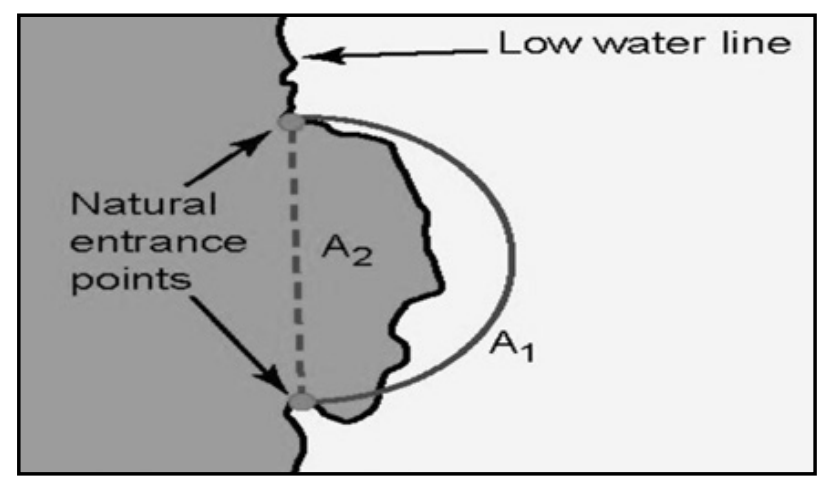

Gambar 2. Bukan Teluk Yuridis

Sumber: International Oceanographic Commission, International Hydrographic Organization, International Association of Geodesy, A Manual on Technical Aspects of United Nation Convention on the Law of the Sea 1982. (Monaco: International Hydrographic Bureau, 2006) hlm.173.

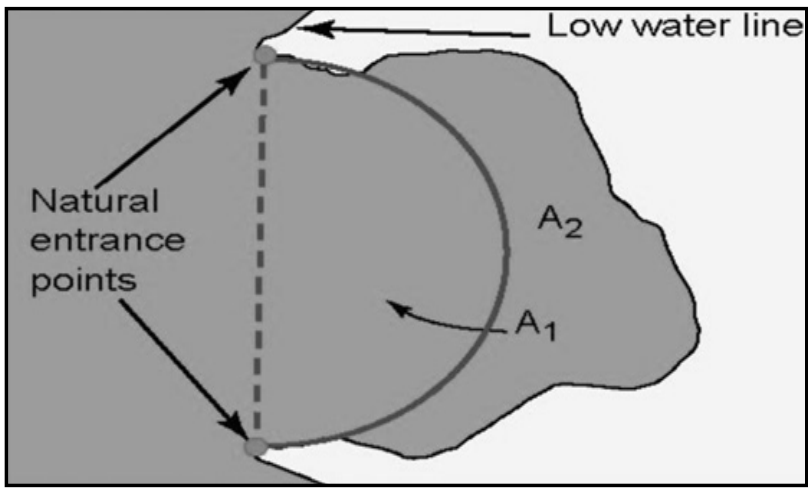

Gambar 3. Teluk Yuridis

Sumber: International Oceanographic Commission, International Hydrographic Organization, International Association of Geodesy, A Manual on Technical Aspects of United Nation Convention on the Law of the Sea 1982. (Monaco: International Hydrographic Bureau, 2006) hlm.173.

Terlihat pada Gambar 2 bahwa wilayah A2 yang dibatasi garis penutup teluk dan garis air rendah dari lekukan teluk lebih sempit daripada wilayah di dalam setengah lingkaran A1, dan karena itu tidak dapat dikategorikan sebagai teluk yuridis. Sedangkan pada Gambar 3 wilayah A2 yang dibatasi garis penutup teluk dan garis air rendah dari lekukan teluk lebih luas daripada wilayah setengah lingkaran A1 dan oleh karena itu dapat dikategorikan sebagai teluk yuridis ${ }^{21}$.

\section{3) Instalasi Pelabuhan}

Instalasi pelabuhan merupakan struktur/ bangunan buatan manusia permanen di sepanjang pantai yang merupakan bagian tak terpisahkan dari sistem pelabuhan. Hal ini meliputi pangkalan pelabuhan (Jetties), tanggul-tanggul, dermaga (quays), atau fasilitas pelabuhan lainnya, terminal

\footnotetext{
$20 \quad$ Ibid, hlm.19.

21 International Oceanographic Commission, International Hydrographic Organization, International Association of Geodesy, "A Manual on Technical Aspects of United Nation Convention on the Law of the Sea 1982" (Monaco: International Hydrographic Bureau, 2006), hlm.4-5.
} 
pesisir, pemecah gelombang (breakwaters), dinding laut (sea walls) dan lain-lain seperti yang jelaskan pada TALOS, 2006. Instalasi pelabuhan seperti disebutkan di atas dapat digunakan sebagai lokasi titik pangkal untuk tujuan penentuan garis pangkal laut teritorial dan zona maritim lainnya. ${ }^{22}$

\section{b. Yurisdiksi Perairan Pedalaman}

Perairan pedalaman merupakan perairan yang berada di sisi dalam garis pangkal yang diukur kearah daratan. Perairan pedalaman (internal waters) ini terjadi karena sebagai akibat dari penarikan garis pangkal lurus dari ujung ke ujung. Dengan penerapan garis pangkal lurus ini pada pantai yang berliku-liku atau pada pantai yang di depannya terdapat pulau atau gugusan pulau, maka akan mengakibatkan adanya bagian perairan atau laut yang terletak di sebelah dalam dari garis pangkal lurus tersebut. Perairan inilah yang disebut dengan perairan pedalaman. Namun, apabila pada pantai yang garis pangkalnya hanya diterapkan garis pangkal normal, maka tidak akan terdapat laut pedalaman, yang ada hanyalah perairan darat, yaitu bagian perairan yang terletak di sebelah dalam garis pangkal normal. ${ }^{23} \mathrm{Di}$ dalam garis pangkal kepulauan, suatu negara kepulauan dapat menarik garis penutup di mulut sungai, teluk, dan pelabuhan pada suatu pulau sesuai dengan aturan biasa terkait dengan garis pangkal. ${ }^{24}$ Perairan ini dikenal dengan istilah perairan pedalaman.

Kedaulatan dari negara pantai meliputi perairan pedalamannya berlanjut pada ruang udara yang ada di atasnya, termasuk dasar laut dan tanah di bawahnya. Suatu negara pantai dapat melaksanakan kedaulatannya secara penuh di perairan pedalaman sebagaimana pelaksanaan kedaulatan di wilayah daratan. ${ }^{25}$ Sebuah kapal asing yang secara sukarela memasukipelabuhan atau perairan pedalaman suatu negara pantai menempatkan dirinya sepenuhnya tunduk pada yurisdiksi teritorial negara pantai, kecuali jika terdapat perjanjian antara negara pantai dan negara bendera. Oleh karena itu, negara pantai tidak hanya menentukan aturan tetapi juga menegakkan aturan-aturan mereka dengan cara eksekutif atau ajudikatif terhadap kapal asing, awak kapal, penumpang dan barang di atas kapal. Kapal asing diharuskan untuk mematuhi ketentuan-ketentuan yang berlaku di negara pantai, khususnya berkenaan dengan bea cukai, keselamatan, kesehatan, navigasi dan administrasi pelabuhan di pelabuhan dan bagian lain perairan pedalaman.

Negara pantai dapat menggunakan yurisdiksi teritorialnya atas kapal asing di pelabuhan atau perairan pedalamannya, hal ini tidak berlaku untuk kapal yang masuk ke perairan pedalaman secara terdesak karena marabahaya atau force majeure. Dengan demikian kapal dapat dibebaskan dari kewajiban yang timbul tak terhindarkan dari masuknya mereka ke pelabuhan atau bagian perairan pedalaman yang sedang dalam mengalami force majeure. Namun beberapa kapal yang sedang mengalami marabahaya masih diharapkan untuk patuh hukum

I Made Andi Arsana, Batas Maritim Antarnegara, Sebuah Tinjauan Teknis dan Yuridis (Yogyakarta: Gadjah Mada University Press, 2007), hlm. 20.

23 I Wayan Parthiana, Pengantar Hukum Internasional (Bandung: Mandar Maju, 1990), hlm. 139.

24 Kresno Buntoro, Alur Laut Kepulauan Indonesia (ALKI) Prospek dan Kendala, (Jakarta: Sekolah Staf dan Komando TNI AL), hlm. 18.

25 Ibid. 
dan peraturan negara pantai di perairan pedalaman. Selain itu, sebagai aturan yang luar biasa, kekebalan dari yurisdiksi negara pantai dalam kasus force majeure harus ditafsirkan dengan cara yang terbatas. Akibatnya, jika keadaan darurat sebuah kapal secara sengaja dilakukan oleh awak kapal, atau sebuah kapal yang dalam keadaan force majeure terdapat niatan melakukan tindakan melawan hukum terhadap negara pantai, maka kapal tersebut dapat kehilangan kekebalannya ${ }^{26}$.

\section{Praktik Negara-Negara Kepulauan Dalam Menerapkan Pasal 50 UNCLOS}

\section{a. Antigua Dan Barbuda}

Antigua dan Barbuda adalah Negara kepulauan $^{27}$ yang merupakan bagian dari "Lesser Antilles" di Karibia Timur. Antigua dan Barbuda terdiri atas tiga pulau, dua pulau utama yaitu Pulau Antigua dan Barbuda, dan satu pulau kecil yaitu Pulau Redonda. Tiga pulau tersebut digunakan untuk menggambar garis pangkal kepulauannya. Garis pangkal kepulauan Antigua dan Barbuda terdiri dari 22 segmen garis, mulai dari 0,05 nm (segmen 16-17) menjadi 52,9 nm (segmen 5-6), dengan total panjang $142 \mathrm{~nm}^{28}$. Garis pangkal kepulauan Antigua dan Barbuda telah memenuhi rasio perbandingan antara daerah perairan dan daerah daratan sebagaimana diatur dalam ketentuan Pasal 47 Ayat (1) UNCLOS $^{29}$. Luas Keseluruhan $3625 \mathrm{~km}^{2}$, Wilayah Perairan $3,182.4 \mathrm{~km}^{2}$, Wilayah
Daratan 442,6 km², Rasio antara wilayah periaran dan daratan adalah 7.19: 1 .

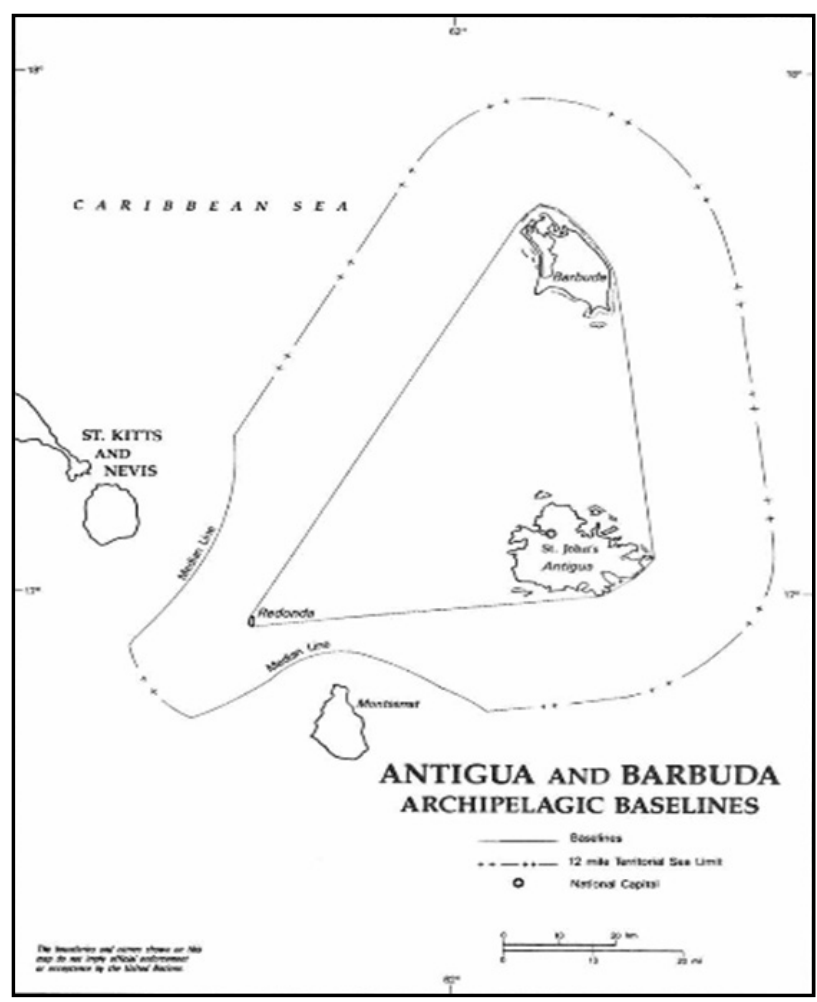

Gambar 4. Peta Ilustratif Garis Pangkal Kepulauan Antigua dan Barbuda

Sumber : Office for Ocean Affairs and the Law of the Sea, United Nations, The Law of the Sea Practice of Archipelagic States, (United Nations: New York, 1992), $\mathrm{h} / \mathrm{m}, 16$.

Berkaitan dengan penerapan Pasal 50 UNCLOS yang mengatur mengenai penarikan garis-garis penutup untuk keperluan penetapan batas perairan pedalaman, telah diatur dalam Pasal 2 huruf (a) dan Pasal 18 Huruf A Antigua and Barbuda Maritime Areas Act, $1982^{30}$. Pada lampiran Antigua

\footnotetext{
26 Ibid, hlm.85.

27 Antigua and Barbuda. Maritime Areas Act, 1982.

28 Bureau of Oceans and International Enviromental and Scientific Affairs, United States Departement of State, "Limits in the Seas No. 133 Antigua and Barbuda : Archipelagic and other Maritime Claims and Boundaries," United States Departement of State, https://www.state.gov/documents/organization/224316.pdf . (diakses 11 November 2018).

29 Ibid.

$30 \quad$ Antigua dan Barbuda. Maritime Areas. Act No. 18 of 17 August 1982.
} 
and Barbuda Maritime Areas Act, 1982 dinyatakan wilayah perairan pedalaman Antigua and Barbuda, yakni St Johns Harbour, Deep and Galley Bays, Five Island Harbour, Mosquito Cove, Cades Bay Lagoon, Carlisle Bay, Falmouth Harbour, English Harbour, Indian Creek, Mamora Bay, Willoughby Bay, Hudson Cove, Half Moon Bay, Exchange Bay, Marigalante Bay, Nonsuch Bay, Belfast \& Guiana Bay, Unnamed, Parham Harbour, Goat Island Flush, Codrington Lagoon ${ }^{31}$. Namun penentuan perairan pedalaman pada daerahdareah tersebut di atas tidak disertai dengan informasi koordinat geografis penetapan batas perairan pedalaman. ${ }^{32}$

\section{b. Fiji}

Fiji merupakan negara kepulauan ${ }^{33}$ yang terletak di barat daya Samudera Pasifik, terdiri dari sekitar 320 pulau-pulau mulai dari ukuran Viti Levu $\left(10.390 \mathrm{~km}^{2}\right)$. Luas daratan keseluruhan Fiji (tidak termasuk daerah air dalam terumbu karang tepi) adalah sekitar $18.272 \mathrm{~km}^{2}$. Untuk tujuan Marine Spaces Act, Pemerintah Fiji membagi atas Fiji Islands, Island of Rotuma Islands, dan Island of Cevai-Ra. Karena berdasarkan ketentuan UNCLOS jarak antara Pulau Rotuma dan Pulau Cevai-Ra, tidak memungkinkan bagi Fiji untuk menarik satu garis pangkal kepulauan yang akan menggabungkan setiap pulau ${ }^{34}$.

Berkaitan dengan penerapan Pasal 50 UNCLOS yang mengatur mengenai penarikan garis-garis penutup untuk keperluan penetapan batas perairan pedalaman, ketentuan Fiji menetapkan dua tipe garis pangkal yang berbeda. Garis pangkal kepulauan dengan sebagian besar pulaupulau di negara itu untuk membentuk Negara Kepuluan Fiji, sisi luar dari garis dasar tersebut merupakan laut teritorial dan laut lepas, dan sisi dalam dari garis dasar tersebut merupakan perairan kepulauan dan perairan Pedalaman. Garis pangkal lainnya adalah garis pangkal yang membatasi antara perairan pedalaman dengan perairan kepulauan. Ketentuan yang mengatur mengenai penutupan garis untuk keperluan perairan pedalaman Fiji diatur dalam Chapter 158A Ed. 1978 Marine Spaces. Penutupan batas perairan pedalaman Fiji telah digambarkan dalam Peta British Admiralty Chart Nomor 2691 dan Nomor 2992.

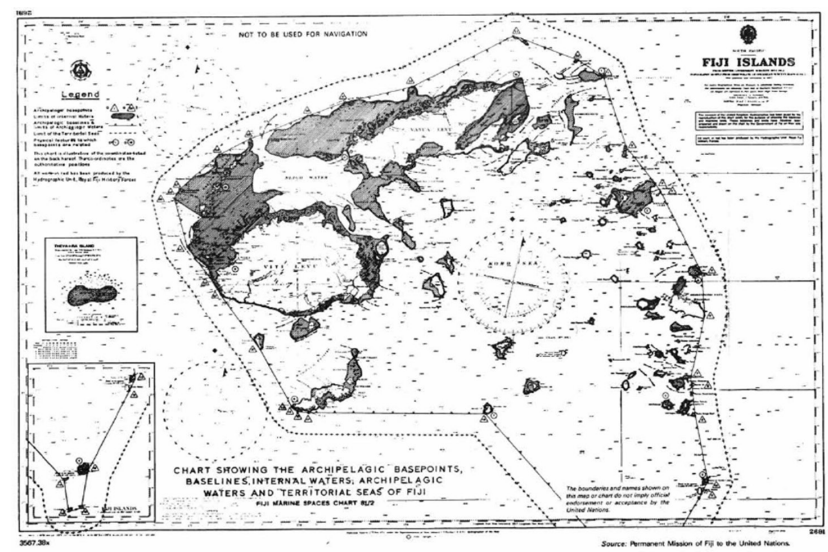

Gambar 5. Peta Ilustratif Garis Pangkal Kepulauan Fiji.

Sumber: Office for Ocean Affairs and the Law of the Sea, United Nations, The Law of the Sea Practice of Archipelagic States. (United Nations: New York, 1992), hlm, 42.

$31 \quad$ Ibid. Ps. 2 huruf (a).

32 Bureau of Oceans and International Enviromental and Scientific Affairs, United States Departement of State, "Limits in the Seas No. 133 Antigua and Barbuda : Archipelagic and other Maritime Claims and Boundaries," United States Departement of State, https://www.state.gov/documents/organization/224316.pdf . (diakses 11 November 2018).

$33 \quad$ Fiji. Marine Spaces Act. 1977.

34 United States Departement of State, Bureau of Intelligence and Research, "Limits in the Seas No. 101 Fiji's Maritime Claims," United States Departement of State, https://2009-2017.state.gov/documents/ organization/58567.pdf . (diakses 30 November 2018). 


\section{c. Cape Verde}

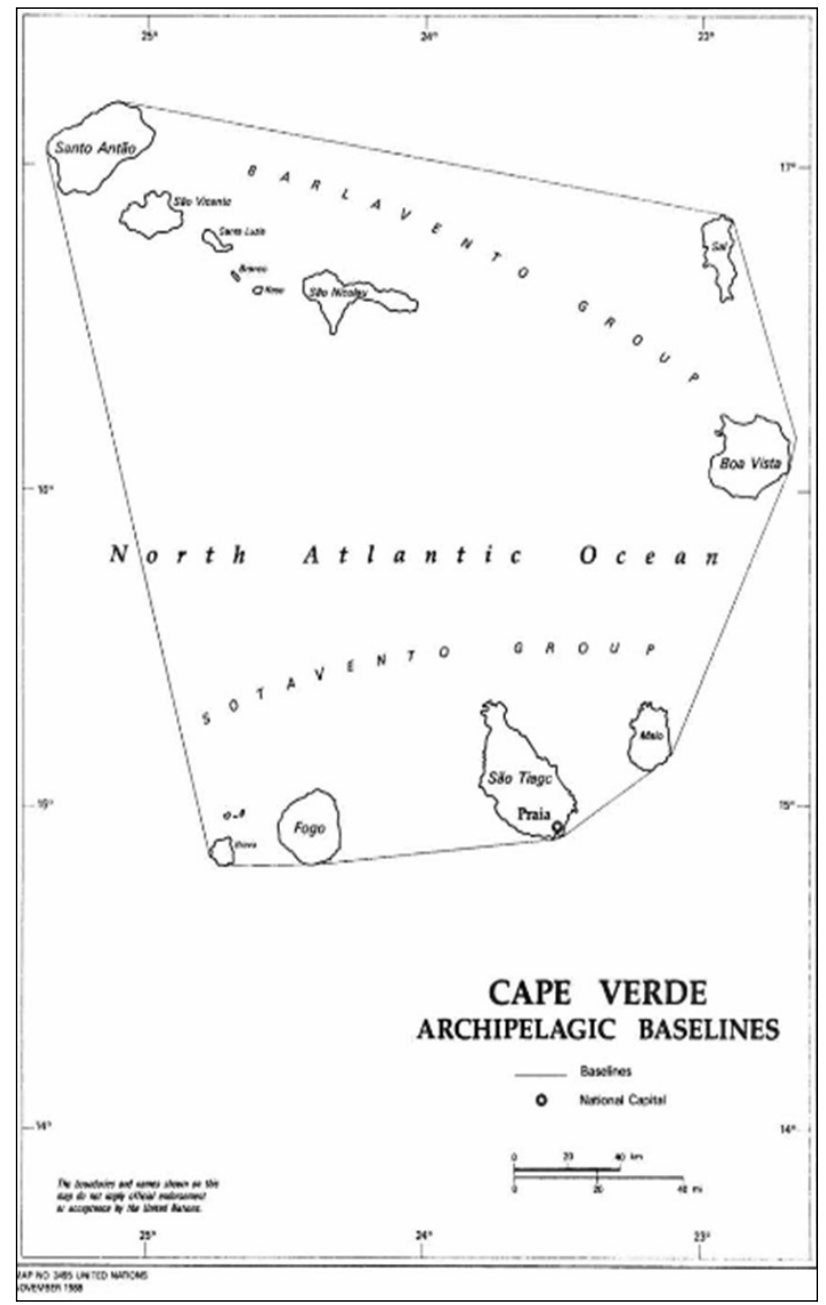

Gambar 6. Peta Ilustratif Garis Pangkal Kepulauan Cape Verde.

Sumber : Office for Ocean Affairs and the Law of the Sea, United Nations, The Law of the Sea Practice of Archipelagic States. (United Nations: New York, 1992), hlm, 19.

Cape Verde merupakan Negara kepulauan ${ }^{35}$ yang terletak di Samudera Atlantik Utara di sebelah Mauritania dan Senegal. Cape Verde terdiri dari delapan pulau utama, dan sejumlah pulau-pulau kecil dan fitur lainnya.
Beberapa pulau dan fitur digunakan untuk menggambar garis pangkal kepulauan. Garis pangkal kepulauan Cape Verde terdiri dari 25 segmen garis, mulai dari 0,42 $\mathrm{nm}$ (segmen F-P1 ke F) ke 99,88 nm (segmen C-P1 untuk D-P1), dengan total panjang $539 \mathrm{~nm}^{36}$.

Berkaitan dengan penerapan Pasal 50 UNCLOS yang mengatur mengenai penarikan garis-garis penutup untuk keperluan penetapan batas perairan pedalaman, telah diatur dalam Pasal 4 Cape Verde Law No. 60/ IV/92 of December 21, 1992 yang menentukan sebagai berikut:

"The Republic of Cape Verde may, within its archipelagic waters, draw baselines for the delimitation of internal waters."

Namun demikian Cape Verde belum melakukan penarikan garis-garis penutup pada mulut sungai, teluk dan instalasi pelabuhannya untuk keperluan penetapan batas perairan pedalaman.

\section{d. Komoro}

Komoro adalah Negara kepulauan ${ }^{37}$ yang terletak di ujung utara Selat. Mozambik di Samudera Hindia antara utara Mozambik dan utara Madagaskar. Komoro terdiri atas tiga pulau utama dan sejumlah pulau-pulau kecil dan fitur lainnya. Garis pangkal kepulauan Komoro terdiri dari 13 segmen garis, mulai dari 1,65 nm (segmen MA) ke 91, $61 \mathrm{mn}$ (segmen $\mathrm{CD}$ ), dengan total panjang $345 \mathrm{~nm}^{38}$. Garis pangkal kepulauan Komoro telah memenuhi

35 Cape Verde. Law No. 60/IV/92. 21 December 1992.

36 Bureau of Oceans and International Enviromental and Scientific Affairs, United States Departement of State, "Limits in the Seas No. 129 Cabo Verde: Archipelagic and other Maritime Claims and Boundaries.," United States Departement of State, https://2009-2017.state.gov/documents/organization/221365.pdf. (diakses 15 November 2018).

37 Komoro. Relating to the Delimitation of the Maritime Zones of the Islamic Federal Republic of the Comoros. Law No. 82-005. of 6 May 1982.

38 Bureau of Oceans and International Enviromental and Scientific Affairs, United States Departement of State, "Limits in the Seas No.134 Comoros: Archipelagic and other Maritime Claims and Boundaries.," United States 
rasio perbandingan antara daerah perairan dan daerah daratan sebagaimana diatur dalam ketentuan Pasal 47 Ayat (1) UNCLOS ${ }^{39}$. Luas keseluruhan $17,847 \mathrm{~km}^{2}$, Wilayah perairan $15,612 \mathrm{~km}^{2}$, Wilayah daratan $2235 \mathrm{~km}^{2}$, Rasio antara wilayah periaran dan daratan adalah 6.99: 1.

Berkaitan dengan penerapan Pasal 50 UNCLOS yang mengatur mengenai penarikan garis-garis penutup untuk keperluan penetapan batas perairan pedalaman, belum diatur dalam ketentuan perundang-undangan Komoro.

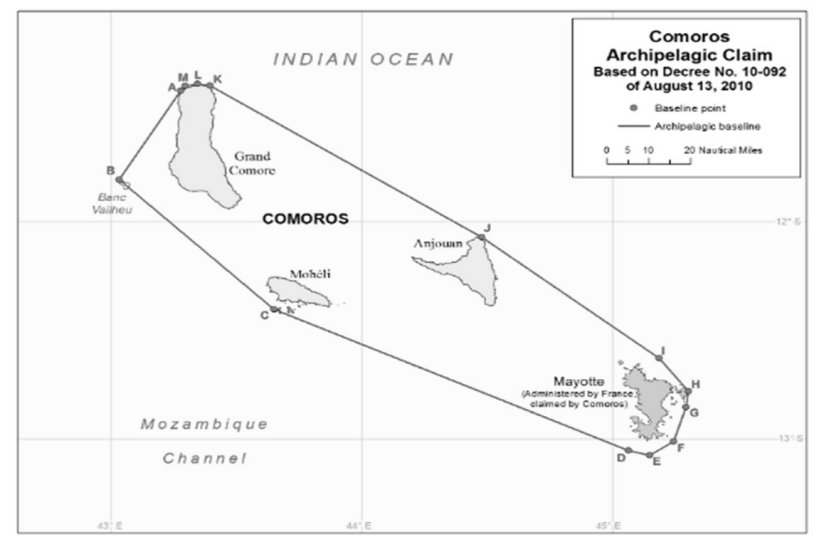

Gambar 7. Peta llustratif Garis Pangkal Kepulauan Komoro

Sumber: Bureau of Oceans and International Enviromental and Scientific Affairs, United States Departement of State, "Limits in the Seas No.134 Comoros: Archipelagic and other Maritime Claims and Boundaries.," United States Departement of State, https://2009-2017.state. gov/documents/organization/224317.pdf. (diakses 30 November 2018).

\section{e. Filipina}

Republik Filipina merupakan negara kepulauan ${ }^{40}$ yang terletak di Asia Tenggara, di Samudera Pasifik Barat di antara Laut Filipina dan Laut Cina Selatan, sebelah timur dari Vietnam, sebelah utara dari Malaysia dan Indonesia, dan selatan Taiwan. Filipina terdiri tas lebih dari 7.000 pulau dan fitur lainnya. Garis pangkal kepulauan Filipina terdiri dari 101 segmen garis, memiliki panjang yang bervariasi mulai dari 0,08 $\mathrm{nm}$ (segmen 99100) sampai dengan $122,88 \mathrm{~nm}$ (segmen 46 47), dengan total panjang $2.808 \mathrm{~nm}$. Garis pangkal kepulauan Filipina mencakup semua pulau utama Filipina dan tidak termasuk Scarborough Reef atau Kepulauan Kalayaan ${ }^{41}$.

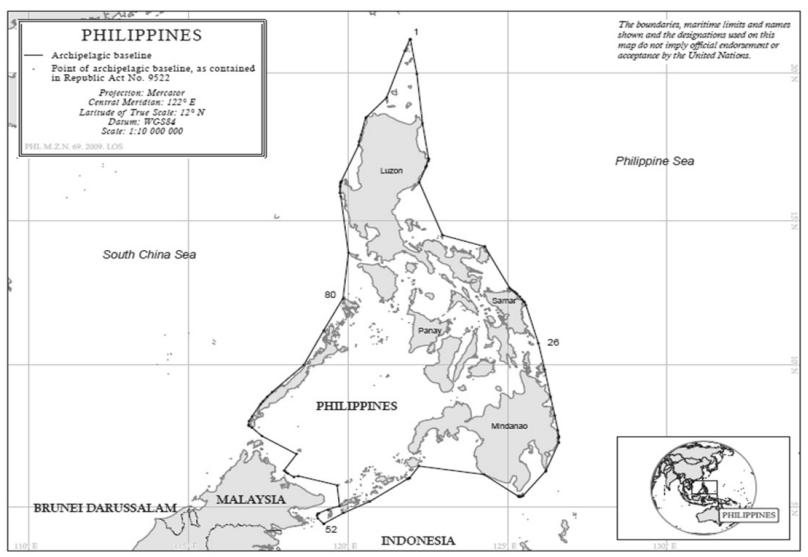

Gambar 8. Peta Ilustratif Garis Pangkal Kepulauan Filipina

Sumber : Division for Ocean Affairs and the Law of the Sea Office of Legal Affairs, United Nations."Bulletin No.70 Law of the Sea," United Nations, http://www.un.org/Depts/ los/doalos_publications/LOSBulletins/_bulletinpdf/ bulletin70e.pdf (diakses 19 Desember 2018).

Departement of State, https://2009-2017.state.gov/documents/organization/224317.pdf. (diakses 30 November 2018).

39 Ibid.

40 Filipina. Define the Baselines of the Territorial Sea of the Philippines. Republic Act No. 3046 of 17 June 1961.

41 Bureau of Oceans and International Enviromental and Scientific Affairs, United States Departement of State, "Limits in the Seas No.142 Philippines Archipelagic and Other Maritime Claims and Boundaries," United States Departement of State, https://2009-2017.state.gov/documents/organization/231914.pdf, (diakses 15 September 2018). 
Garis pangkal kepulauan Filipina memenuhi area rasio perbandingan antara daerah perairan dan daerah daratan sebagaimana diatur dalam ketentuan Pasal 47 ayat (1) UNCLOS ${ }^{42}$. Luas keseluruhan $887.909 \mathrm{~km}^{2}$, wilayah perairan $589.739 \mathrm{~km}^{2}$, wilayah daratan $298.170 \mathrm{~km}^{2}$, rasio antara wilayah periaran dan daratan adalah 1,98: 1 .

Berkaitan dengan penerapan Pasal 50 UNCLOS yang mengatur mengenai penarikan garis-garis penutup untuk keperluan penetapan batas perairan pedalaman. Pasal 1 Konstitusi Filipina menyatakan:

"[t]he waters around, between, and connecting the islands of the archipelago, regardless of their breadth and dimensions, form part of the internal waters of the Philippines."

Pada saat menandatangani dan meratifikasi UNCLOS pada tahun 1984, Filipina menyatakan:

"The concept of archipelagic waters [under the LOS Convention] is similar to the concept of internal waters under the Constitution of the Philippines"

Pandangan ini mendapatkan protes dari Amerika Serikat dan negara-negara lain. Sebagai tanggapan, pada tahun 1988 Filipina menyatakan bahwa pihaknya "bermaksud untuk menyelaraskan perundang-undangan domestiknya dengan ketentuan-ketentuan UNCLOS dan bahwa Filipina "akan mematuhi ketentuan-ketentuan Konvensi tersebut ${ }^{43}$. Pada tahun 2011, "Philippine Maritime Zones Act" diajukan kepada kongres Filipina, Pada bagian 4 akan menjelaskan, kosistensi atas UNCLOS, bahwa: [t] he Archipelagic Waters of the Philippines refer to the waters on the landward side of the archipelagic baselines ..." and that "[w] ithin the archipelagic waters, closing lines for the delimitation of internal water shall be drawn pursuant to Article 50 of [the LOS Convention]...."

Ketentuan ini, telah memberikan konfirmasi bahwa Filipina akan menerapkan ketentuan yang mengatur perairannya sesuai dengan UNCLOS, hingga bulan mei 2014 ketentuan tersebut belum diberlakukan menjadi Undang-Undang.

\section{f. Indonesia}

Indonesia telah mengakomodir ketentuan Pasal 50 UNCLOS di dalam Pasal 7 ayat (1) Undang-Undang Nomor 6 Tahun 1996 tentang Perairan Indonesia yang menentukan bahwa: “Di dalam perairan kepulauan, untuk penetapan batas perairan pedalaman, Pemerintah Indonesia dapat menarik garis-garis penutup pada mulut sungai, kuala, teluk, anak laut, dan pelabuhan". Namun hal tersebut hanya dalam bentuk formulasi ketentuan karena Indonesia belum menentukan perairan pedalaman Indonesia secara formal ${ }^{44}$. Tentunya hal ini akan sangat merugikan Indonesia khususnya dalam bidang pertahanan dan kemanan di Indonesia, karena apabila Indonesia tidak melakukan penutupan garis batas perairan pedalaman maka kapal asing tidak mempunyai batasan wilayah untuk melaksanakan lintas damai di perairan Indonesia. Tetapi perkembangan terakhir menunjukan hal yang positif dari pemerintah Indonesia, melalui Kementerian

\footnotetext{
42 Ibid.

43 Ibid. hlm.4

44 Kresno Buntoro, Alur Laut Kepulauan Indonesia (ALKI) Prospek dan Kendala, (Jakarta: Sekolah Staf dan Komando TNI AL, 2012), hlm. 23.
} 
Koordinator Bidang Kemaritiman bekerjasama dengan Badan Informasi Geospasial, Pusat Hidrografi dan Oseanografi TNI Angkatan Laut, dan Tim Teknis Geodesi Universitas Gajah Mada sedang melaksanakan identifikasi dan pengkajian mengenai penetapan batas perairan pedalaman Indonesia.

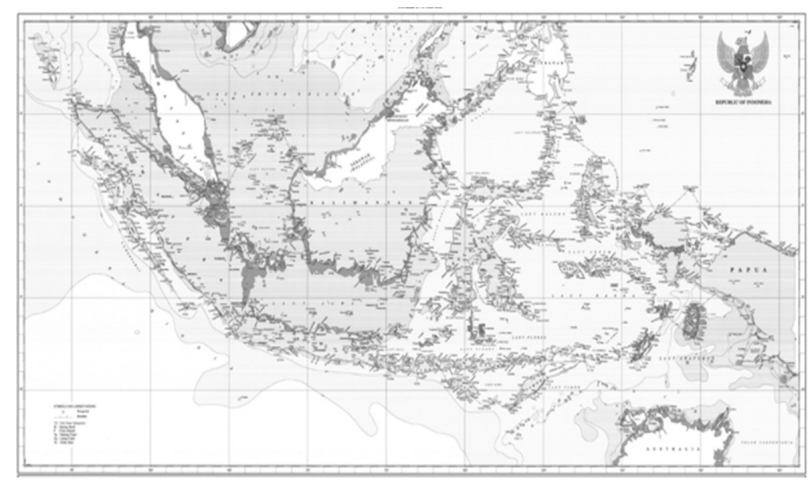

Gambar 9. Peta Ilustratif Garis Pangkal Kepulauan Indonesia.

Sumber: Divison for Ocean Affairs and the Law of the Sea, United Nations, "Illustrative Map of the Geographical Coordinates Of Points of the Indonesian Archipelagic Baselines," United Nations, http://www.un.org/Depts/ Ios/LEGISLATIONANDTREATIES/PDFFILES/MAPS/idn_ mzn67_2009.jpg (diakses 30 November 2018).

Telah dilaksanakan beberapa kegiatan pertemuan dan focus group discussion mengenai penetapan perairan pedalaman Indonesia yang diinisiasi oleh Kementerian Koordinator Bidang Maritim dengan mengundang instasi terkait pada tanggal 3 Agustus 2018, 21 September 2018, 8 Oktober 2018, 19 Oktober 2018, 26 Oktober 2018, 16 November 2018 di Yogyakarta; dan 17 Desember 2018 di Bali ${ }^{45}$. Penetapan perairan pedalaman Indonesia akan dilaksanakan secara menyeluruh yakni terhadap mulut sungai, teluk dan pelabuhan. Untuk saat ini diawali denganmengidentifikasi penutupan teluk-teluk di Indonesia terlebih dahulu.
Berdasarkan hasil identifikasi Tim Teknis Penetapan Perairan Pedalaman, sampai dengan Desember 2018 telah dilakukan identifikasi teluk yang berada di Pulau Jawa, papua, dan kalimantan, serta teluk yang bersinggungan dengan jalur ALKI. Dengan rincian sebagai berikut:

a. Pulau Jawa terdapat 190 teluk, 67 teluk merupakan teluk yuridis, dan 123 teluk merupakan teluk non yuridis.

b. Pulau Papua terdapat 401 teluk bertoponimi (bernama), 190 teluk merupakan yuridis, dan 211 merupakan teluk non yuridis.

c. Pulau Kalimantan terdapat 44 teluk bertoponimi, 21 teluk merupakan teluk yuridis dan 23 teluk merupakan teluk non yuridis.

d. Jalur ALKI terdapat 103 teluk, 51 teluk merupakan teluk yuridis dan 52 teluk merupakan teluk non yuridis.

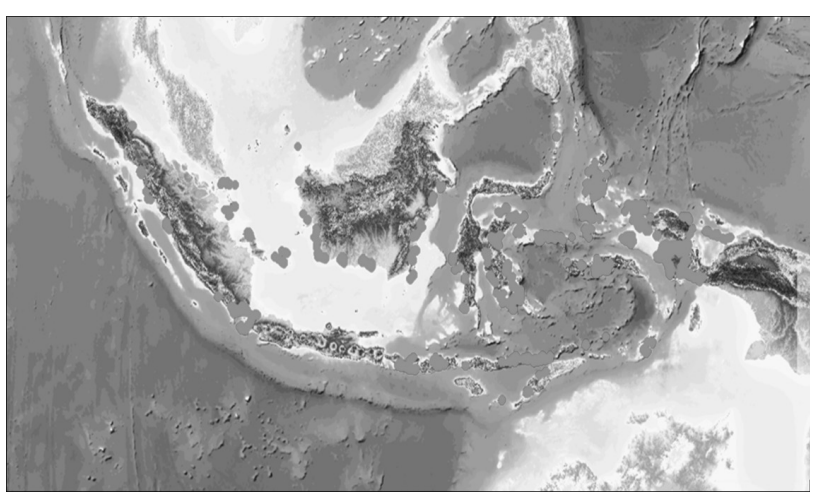

Ket : Hasil identifkasi teluk yuridis

Gambar 10. Peta Ilustrasi Hasil Indentifikasi sementara Teluk Yuridis

Sumber: Astrit Rimayanti, Perairan Pedalaman Indonesia, Paparan disampaikan pada rapat review Penetapan Perairan Pedalaman Indonesia di Kementerian Koordinator Bidang Kemaritiman (Jakarta, 8 Januari 2019)

45 Bagian Hukum Pushidrosal, Laporan Rapat Reviu Penetapan Perairan Pedalaman Indonesia, 16 - 18 Desember 2018. 


\section{Penutup}

Negara-negara pantai menikmati yurisdiksi teritorial penuh dan lengkap atas perairan pedalaman. Oleh karena itu menjadi hal yang sangat penting bagi negara pantai untuk menetapkan batas perairan pedalamannya. Pasal 50 UNCLOS telah memberikan hak kepada Negara Kepulauan untuk dapat menutup batas perairan pedalamannya pada mulut sungai, teluk dan pelabuhan. Dalam praktek negara kepulauan terdapat negara yang telah mengakomodir Pasal 50 UNCLOS dalam peraturan nasionalnya dan telah menerapkannya contoh Antiqua dan Barbuda, dan Fiji. Tetapi juga terdapat negara yang tidak mengakomodir Pasal 50 UNCLOS karena mempunyai pandangan berbeda terhadap perairan pedalamannya contoh Negara Filipina.

Indonesia termasuk negara yang telah mengakomodir Pasal 50 UNCLOS di dalam Pasal 7 ayat (1) Undang-Undang No. 6 Tahun 1996 tentang Perairan Indonesia, namun belum melaksanakan penetapan perairan pedalamannya. Tetapi perkembangan terakhir menunjukan hal yang positif dari pemerintah Indonesia, melalui Kementerian Koordinator Bidang Kemaritiman bekerjasama dengan Badan Informasi Geospasial, Pusat Hidrografi dan Oseanografi TNI Angkatan Laut, dan Tim Teknis Geodesi Universitas Gajah Mada sedang melaksanakan identifikasi dan pengkajian mengenai penetapan batas perairan pedalaman Indonesia.

Garis-garis penutup untuk keperluan penetapan batas perairan pedalaman menjadi hal yang sangat penting bagi Indonesia, sehingga dalam melakukan penetapan batas perairan pedalaman perlu adanya koordinasi yang intensif dan kohemperensif antara kementerian dan lembaga yang terkait. Selain itu Pemerintah Indonesia perlu mendorong pengaturan mengenai penetapan batas perairan pedalaman dalam bentuk UndangUndang. Undang-undang tersebut memuat batas-batas perairan pedalaman Indonesia dengan menyertakan koordinat geografis, dan pemerintah Indonesia menggambarkan batas perairan pedalaman Indonesia yang telah ditetapkan oleh Undang-Undang pada Peta Laut Indonesia.

\section{Daftar Pustaka}

\section{Buku}

Adolf, Huala, Aspek-aspek Negara dalam Hukum Internasional, Cet.kedua (Jakarta: Raja Grafindo Persada, 1996).

Arsana, I Made Andi, Batas Maritim Antarnegara, Sebuah Tinjauan Teknis dan Yuridis (Yogyakarta: Gadjah Mada University Press, 2007).

Barrett, Jill and Richard Barnes, Law of the Sea:UNCLOS as a Living Treaty (British Institute of International and Comparative Law, 2016).

Buntoro, Kresno, Alur Laut Kepulauan Indonesia (ALKI) Prospek dan Kendala (Jakarta: Sekolah Staf dan Komando TNI AL, 2012).

Nusantara dan (ALKI) Alur Laut Kepulauan Indonesia (Bandung: Rajawali Pers, 2017).

Butcher, John G and R.E. Elson, Sovereignty and the Sea How Indonesia Became an Archipelage State (Singapore: Nus Press, 2017).

Brown, E.D., The International Law of the Sea, Introductory Manual (USA-Singapore-Sydney, Dartmouth, Aldershot-Brookfield, 1994).

Churchill, R. dan A Lowe, The Law of the Sea (Manchaster: Manchaster University Perss, 1999).

International Oceanographic Commission, International Hydrographic Organization, International Association of Geodesy, A Manual on Technical Aspects of United Nation Convention on the Law of the Sea 1982 (Monaco: International Hydrographic Bureau, 2006). 
Kusumaatmadja, Mochtar, Hukum Laut Internasional (Bandung: Bina Cipta. 1978).

Kusumaatmadja, Mochtar, Bunga Rampai Hukum Laut (Bandung: Bina Cipta. 1978).

Kusumaatmadja, Mochtar, Pengantar Hukum Internasional (Bandung: Bina Cipta. 1978).

Mohamad Sodik, Dikdik, Hukum Laut Internasional dan Pengaturannya di Indonesia (Bandung: Refika Aditama, 2014).

Muhjidin, Atje Misbach, Status Hukum Perairan Kepulauan Indonesia dan Hak Lintas Kapal Asing (Bandung: Alumni, 1993).

Parthiana, I Wayan, Hukum Laut Internasional dan Hukum Laut Indonesia (Bandung: Yrama Widya, 2014).

Proelss, Alexander et al., United Nations Convention on the Law of the Sea; a Commentary ( C.H. Beck, 2017).

Sjawie, Hasbullah F, Negara Kepulauan Indonesia dan Hukum Laut Internasional (Jakarta: Serambi Ilmu Semesta, 2001).

Soekanto, Soejono, Pengantar Penelitian Hukum ( Jakarta: Penerbit UI Pers, 1986).

Tangsubkul, Phipat dan J. Saravanamuttu, ASEAN and the Law of the Sea (Singapore: Institute of Southeast Asian Studies,1985).

Winarti, Indien, Konsep Negara Kepulauan, Perspektif Hukum Laut dan Penetapan Garis Batas Negara (Malang: Setara Press, 2016).

Yang, Haijiang, Jurisdiction of the Coastal State over Foreign Merchant Ships in Internal Waters and the Territorial Sea (Heidelberg: Springer Berlin, 2006)

Perserikatan Bangsa-Bangsa, Yearbook of the International Law Commission, Vol II, Document A/CN. 4/99 (1956).

\section{Makalah/Artikel/Prosiding/Laporan/Hasil Penelitian}

Afriansyah, Arie. "Kewenangan Negara Pantai Dalam Mengelola Wilayah Laut", (makalah disampaikan pada Forum Diskusi Aktual (FDA), "Kewenangan Daerah Provinsi Di Laut", Badan Penelitian dan Pengembangan, Kementerian Dalam Negeri, Jakarta, 24 Agustus 2015)

Agoes, Etty R, "Praktik Negara-Negara Atas Konsepsi Negara Kepulauan," Indonesian Jurnal of International Law (2004).

Kusumaatmadja, Mochtar, "Konsepsi Hukum Negara Nusantara Pada Konferensi Hukum Laut KE-III" (1977).
Oegroseno, Arif Havast, "Archipelagic States: From Concept To Law", The Imli Manual On International Maritime Law (2014).

Roach, J. Ashley, "Offshore Archipelagos Enclosed by Straight Baselines: An Excessive Claim?," Ocean Development \& International Law (2018).

Sumardiman, Adi, "Beberapa Dasar Tentang Perbatasan Negara," Indonesian Journal for International Law (2004).

Whomersley, Chris, "Offsore Archipelagos Enclosed By Straight Baselines: A Reply to J. Ashley Roach," Ocean Development \& International Law (2018).

\section{Internet}

Bureau of Intelligence and Research, United States Departement of State, "Limits in the Seas No. 101 Fiji's Maritime Claims," United States Departement of State, https://2009-2017. state.gov/documents/organization/58567. pdf. (diakses 30 November 2018).

Bureau of Oceans and International Enviromental and Scientific Affairs, United States Departement of State, "Limits in the Seas No. 129 Cabo Verde: Archipelagic and other Maritime Claims and Boundaries.," United States Departement of State, https://2009-2017.state.gov/documents/ organization/221365.pdf. (diakses 15 November 2018).

Bureau of Oceans and International Enviromental and Scientific Affairs, "Limits in the Seas No. 133 Antigua and Barbuda : Archipelagic and other Maritime Claims and Boundaries," United States Departement of State, https://www. state.gov/documents/organization/224316. pdf (diakses 11 November 2018).

Bureau of Oceans and International Enviromental and Scientific Affairs,"Limits in the Seas No.134 Comoros: Archipelagic and other Maritime Claims and Boundaries.," United States Departement of State, https://2009-2017. state.gov/documents/organization/224317. pdf. (diakses 30 November 2018).

Bureau of Oceans and International Enviromental and Scientific Affairs,"Limits in the Seas No.142 Philippines Archipelagic and Other Maritime Claims and Boundaries," United States Departement of State, https://2009-2017. 
state.gov/documents/organization/231914. pdf, (diakses 15 September 2018).

Divison for Ocean Affairs and the Law of the Sea, United Nations, "Illustrative Map of the Geographical Coordinates Of Points of the Indonesian Archipelagic Baselines," United Nations, http://www.un.org/Depts/los/ LEGISLATIONANDTREATIES/PDF FILES/MAPS/ idn_mzn67_2009.jpg (diakses 30 November 2018).

\section{Peraturan Perundang-Undangan}

Convention on the Law of the Sea, UNTS 1833 (1982).

Philippines, Define the Baselines of the Territorial Sea of the Philippines Republic Act No. 3046 of 17 June 1961.

Fiji. Marine Spaces Act. 1977.

Comoros, Relating to the Delimitation of the Maritime Zones of the Islamic Federal Republic of the Comoros. Law No. 82-005. of 6 May 1982.

Antigua dan Barbuda, Maritime Areas. Act No. 18 of 17 August 1982.
Cape Verde, Law No. 60/IV/92. 21 December 1992.

Undang-Undang Nomor 17 Tahun 1985 Tentang Undang-Undang Tentang Pengesahan United Nations Convention On The Law Of The Sea (Konvensi Perserikatan Bangsa-Bangsa Tentang Hukum Laut).

Undang-Undang Nomor 6 Tahun 1996 Tentang Perairan Indonesia.

Peraturan Pemerintah Nomor 36 Tahun 2002 tentang Hak Dan Kewajiban Kapal Asing Dalam Melaksanakan Lintas Damai Melalui Perairan Indonesia.

Peraturan Pemerintah Nomor 37 Tahun 2002 tentang Hak Dan Kewajiban Kapal Dan Pesawat Udara Asing Dalam Melaksanakan Hak Lintas Alur Laut Kepulauan Melalui Alur Laut Kepulauan Yang Ditetapkan.

Peraturan Pemerintah Nomor 37 Tahun 2008 Tentang Perubahan Atas Peraturan Pemerintah Nomor 38 Tahun 2002 Tentang Daftar Koordinat Geografis Titik-Titik Garis Pangkal Kepulauan Infonesia. 